\title{
Corydoras ortegai, a new species of corydoradine catfish from the lower río Putumayo in Peru (Ostariophysi: Siluriformes: Callichthyidae)
}

\author{
Marcelo R. Britto*, Flávio C. T. Lima** and Max H. Hidalgo***
}

\begin{abstract}
A new species of Corydoras, C. ortegai, is described from tributaries of the lower course of río Putumayo in Peru, close to the border with Brazil and Colombia. The new species seems to be related to Corydoras reynoldsi, C. weitzmani, C. panda, and C. tukano, all of which share a pattern composed of uniform light ground color on body, dark bar ("mask") across orbit, and one or two large rounded blotches midlaterally on trunk. Corydoras ortegai is easily distinguished from these species, except $C$. panda, mainly by the absence of a midlateral trunk blotch at the dorsal-fin level, and the rounded shape of the midlateral trunk blotch at the adipose-fin level. Corydoras ortegai differs from C. panda by its greater number of lateral body plates, lack of dorsal-fin blotch, scattered chromatophores surrounding midregion of cleithrum, caudal fin with series of small blotches restricted to rays, slenderer body, and narrower intercleithral area. Corydoras ortegai belongs to a putatively monophyletic assemblage of Corydoras that occurs mainly in the Western Amazon basin, C. tukano excepted. The occurrence of Corydoras tukano in the rio Tiquié (upper Negro basin) and its putative sister species, C. ortegai, in the western Amazon, together with similar distribution patterns shared by other groups of fishes, suggest a biogeographic relationship between these areas.
\end{abstract}

Uma nova espécie de Corydoras, C. ortegai, é descrita de afluentes do baixo curso do río Putumayo no Peru, próximo a fronteira com o Brasil e Colômbia. A nova espécie parece estar relacionada a Corydoras reynoldsi, C. weitzmani, C. panda e C. tukano, as quais compartilham um padrão de colorido claro e uniforme no corpo, uma faixa escura ("máscara") através da órbita, e uma ou duas manchas grandes e arredondadas no corpo. Corydoras ortegai é facilmente distinta destas espécies, exceto $C$. panda, principalmente pela ausência de uma mancha lateral no corpo na altura da nadadeira dorsal, e a forma arredondada de uma mancha lateral na altura da nadadeira adiposa. Corydoras ortegai difere de C. panda pelo maior número de placas laterais no corpo, ausência de uma mancha dorsal, cromatóforos espalhados ao redor da região mediana do cleitro, nadadeira caudal com séries de pequenas manchas restritas aos raios, corpo mais delgado, e área entre os cleitros mais estreita. Corydoras ortegai é assinalada a um possível grupamento monofilético de Corydoras que ocorrem principalmente na bacia amazônica ocidental, exceto C. tukano. A ocorrência de Corydoras tukano no rio Tiquié (alto curso da bacia do rio Negro) e sua possível espécie irmã, C. ortegai, na Amazônia ocidental, associada a um padrão de distribuição semelhante compartilhado por outros grupos de peixes, sugerem uma relação biogeográfica entre estas áreas.

Key words: Corydoras ortegai, río Putumayo, Callichthyidae, Western Amazon.

\section{Introduction}

The genus Corydoras La Cépède is a large assemblage, currently including more than 150 valid species (Reis, 2003; Fuller \& Evers, 2005). Corydoras is widely distributed in CisAndean South America, occurring in a variety of habitats, such as shallow, marginal areas of rivers and associated flooded areas, and smaller tributaries. Species assigned to Corydoras display a broad diversity of body shapes, coloration, and behavior (for a general account on the group, see Fuller \& Evers, 2005) and much taxonomic work remains to properly assess its diversity.

Thirty species of Corydoras are currently known from Peru (Nijssen \& Isbrücker, 1986; Burguess, 1993, 1997). The

\footnotetext{
*Departamento de Vertebrados, Museu Nacional, Universidade do Rio de Janeiro, Quinta da Boa Vista, 20940-040 Rio de Janeiro, RJ, Brazil.mrbritto2002@yahoo.com.br

**Museu de Zoologia da Universidade de São Paulo, Caixa Postal 42494, 04299-970 São Paulo, SP, Brazil. fctlima@usp.br

***Museo de Historia Natural de la Universidad Nacional Mayor de San Marcos, Av. Arenales 1256, Jesús María, 14-0434 Lima, Peru. maxhhidalgo@yahoo.com
} 
new species of Corydoras was discovered during a recent ichthyological survey conducted by the third author $(\mathrm{MH})$ in small terra firme streams of the lower río Putumayo basin (known as rio Içá in Brazil), in a remote area of the Amazonian lowland rainforest of Loreto, Peru, close to the border with Colombia and Brazil. This undescribed species is similar to Corydoras (i.e. C. reynoldsi Myers \& Weitzman, C. weitzmani Nijssen, C. tukano Britto \& Lima, and C. panda Nijssen \& Isbrücker) that share a pattern composed of light, uniform ground color on body, dark bar ("mask") across orbit, and one or two dark rounded blotches, the first (present or absent) at the dorsal-fin level, and the second (always present) at the adipose-fin level.

\section{Material and Methods}

Morphometric and meristic data were taken following Reis (1997). Length of the ossified portion of pectoral spine was measured from the spine-pectoral girdle articulation to distal tip of spine. Measurements were obtained with $0.1 \mathrm{~mm}$ precision calipers. Teeth and vertebral counts were taken only from cleared-and-stained (cs) specimens, prepared according to Taylor \& Van Dyke (1985). Vertebral counts include only free centra, with the compound caudal centrum (preural $1+$ ural 1) counted as a single element. Lateral plate counts include all dorsolateral and ventrolateral plates, except for a pair of small, irregular platelets on caudal-fin base. In the description, numbers assigned with an asterisk represent counts from the holotype. Nomenclature of latero-sensory canals follows Schaefer \& Aquino (2000), and that of preopercular pores follows Schaefer (1988). Osteological terminology follows Reis (1998a), except by "parieto-supraoccipital" instead of "supraoccipital" (Arratia \& Gayet, 1995), "compound pterotic" instead of "pterotic-supracleithrum" (Aquino \& Schaefer, 2002), and "scapulocoracoid" instead of "coracoid" (Lundberg, 1970). Homology of barbels follows Britto \& Lima (2003). Institutional abbreviations are according to Reis et al. (2003).

\section{Results \\ Corydoras ortegai, new species}

Figs. 1-3

Holotype. MUSM 28000, 32.7 mm SL, Peru, Departamento Loreto, Provincia Maynas, río Putumayo basin, Quebrada Coronel Díaz, tributary to río Yaguas, 2051'13"S, 71²7'02"W (UTM 19M 0231999/9683442), altitude 92 m, 5 Aug 2003; M. Hidalgo \& R. Oliveira.

Paratypes. 102 specimens. All from Peru, Departamento Loreto, Provincia Maynas, río Putumayo basin: MNRJ 29404, 8, 3 cs, 18.9-28.9 mm SL (5, 25.0-28.9 mm SL); MUSM 26961, 23, 12.5$25.8 \mathrm{~mm}$ SL $(12,21.8-25.8 \mathrm{~mm}$ SL); MUSM 27154, 27, 17.0-28.2 mm SL (5, 25.0-28.2 mm SL); MZUSP 91411, 8, 18.4-28.3 mm SL (1, $28.3 \mathrm{~mm} \mathrm{SL})$, collected with the holotype. FMNH 117263, 8,

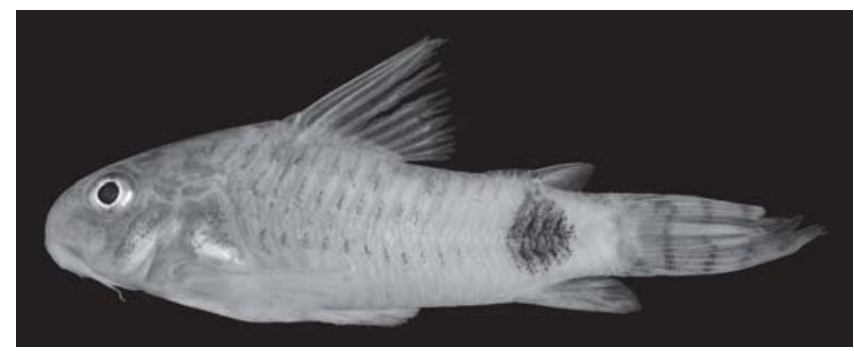

Fig. 1. Corydoras ortegai, MUSM 28000, holotype, $32.7 \mathrm{~mm}$ SL: Peru, Depto. Loreto, Quebrada Coronel Díaz, tributary of río Yaguas.

16.6-18.3 mm SL; MUSM 27155, 28, 18.4-31.2 mm SL (4, 25.9$31.2 \mathrm{~mm} \mathrm{SL}$ ), río Yaguas, 2051'41”S, 71²4'38"W (UTM 19M0231996/9683445), altitude 99 m, 7 Aug 2003; M. Hidalgo \& R. Oliveira.

Diagnosis. Corydoras ortegai is distinguished from all other species of Corydoras, except C. panda, C. reynoldsi, C. weitzmani, and C. tukano, by having a transverse, dark bar ("mask") across the orbit, and ground color of body uniform with large, dark rounded blotch midlaterally on trunk below adipose fin. The new species is distinguished from $C$. reynoldsi, $C$. weitzmani, and $C$. tukano by the absence of a midlateral trunk blotch at the dorsal-fin level, and the rounded shape of the trunk blotch at adipose-fin level. Corydoras ortegai differs from $C$. panda by its greater number of lateral body plates (24 dorsolateral/ 21-22 ventrolateral vs. 22-23/20), dark brown dorsal-fin blotch absent ( $v s$. present), several scattered chromatophores surrounding yellowish white area on midregion of cleithrum ( $v s$. chromatophores absent or nearly absent on cleithrum), caudal fin with narrow series of dark brown blotches restricted to rays ( $v s$. caudal fin hyaline), a slenderer body (depth of body $28.3-35.1 \%$ SL $v s .40 .0 \%$ SL), and a narrower intercleithral area (maximum cleithral width $10.7-15.5 \%$ SL vs. $18 \%$ SL).

Another feature helpful to distinguish the new species from its congeners is the unique condition of its inner mental barbels, which are distinctly separated only at their distal tips ( $v s$. barbels distinctly separated along their entire lengths). Although an exclusive character-state among corydoradine catfishes, this condition is variable among Corydoras ortegai specimens.

Description. Morphometric data presented in Table 1. Head compressed, roughly triangular with rounded apex in dorsal view; dorsal profile slightly convex, nearly straight, rising moderately from nares to tip of parieto-supraoccipital process (Fig. 3). Snout profile rounded from upper lip to horizontal through anterior nares. Dorsal profile of body slightly convex from tip of parieto-supraoccipital process to last dorsalfin ray, then slightly concave to adipose-fin spine and descending straight downwards from this point to caudal-fin base. Ventral profile of body slightly convex from isthmus to 
Table 1. Morphometric data of holotype and paratypes of Corydoras ortegai.

\begin{tabular}{lccc}
\hline & Holotype & \multicolumn{2}{c}{ Paratypes } \\
\cline { 3 - 4 } & \multicolumn{3}{c}{ Mean (n=27) } \\
\hline Standard length (mm) & 32.7 & 25.9 & $21.8-31.2$ \\
& Percents of standard length \\
Depth of body & 32.0 & 31.6 & $28.3-35.1$ \\
Predorsal distance & 46.4 & 46.6 & $39.5-49.9$ \\
Prepelvic distance & 47.7 & 46.6 & $44.2-49.1$ \\
Preanal distance & 84.3 & 81.9 & $76.7-84.4$ \\
Preadipose distance & 85.4 & 82.5 & $80.1-84.0$ \\
Length of dorsal spine & 29.1 & 30.9 & $27.6-34.0$ \\
Length of pectoral spine & 32.3 & 32.4 & $27.4-36.8$ \\
Length of adipose-fin spine & 10.9 & 10.8 & $5.9-12.6$ \\
Depth of caudal peduncle & 14.1 & 14.8 & $13.6-15.9$ \\
Dorsal to adipose distance & 24.7 & 22.0 & $19.4-24.0$ \\
Length of dorsal-fin base & 19.9 & 19.3 & $17.5-21.4$ \\
Maximum cleithral width & 14.7 & 12.6 & $10.7-15.5$ \\
Head length & 39.8 & 40.7 & $37.5-43.6$ \\
Length of maxillary barbel & 15.6 & 14.0 & $10.1-18.7$ \\
& Percents of Head length & \\
Head depth & 79.2 & 78.4 & $73.0-88.4$ \\
Least interorbital distance & 26.0 & 29.0 & $26.4-31.3$ \\
Horizontal orbit diameter & 24.9 & 26.1 & $21.3-30.4$ \\
Snout length & 29.7 & 29.7 & $25.3-34.7$ \\
Least internareal distance & 16.6 & 18.5 & $14.4-23.5$ \\
\hline
\end{tabular}

anal-fin origin, mainly in pectoral- and pelvic-girdle region. Profile markedly straight, ascending obliquely from first analfin ray to caudal-fin base. Body roughly triangular in cross section at pectoral girdle, gradually becoming more compressed toward caudal fin.

Eye round, located dorso-laterally on head; orbit delimited dorsally by frontal and sphenotic, ventrally by infraorbitals. Anterior and posterior nares proximal, only separated by flap of skin. Anterior naris tubular; its free tip with minute, roughly lanceolate, fleshy flap. Posterior naris close to anterodorsal margin of orbit, separated from it by distance slightly smaller than naris diameter. Mouth small, subterminal, width nearly equal to bony orbit diameter. Maxillary barbel elongate, usually reaching anteroventral limit of gill opening (Fig. 3). Outer mental barbel slightly shorter than maxillary barbel. Inner mental barbels short, fleshy and depressed; proximal for much of their lengths, separated only at distal tips in most examined specimens. Small rounded papillae covering entire surface of all barbels, upper and lower lips, and isthmus. Gill membranes united to isthmus. Four branchiostegal rays covered by thin layer of skin; lateralmost two rays united at their distal tips by branchiostegal cartilage. Teeth on upper pharyngeal tooth plate 46 (1), or 50 (1), and on fifth ceratobranchial 31 (1), or 38 (1). Tooth plate rounded.

Nasal, frontal, sphenotic, compound pterotic, and parietosupraoccipital visible externally, all covered by thin layer of skin and bearing minute scattered odontodes. Frontal fontanel elongate, ellipsoid, covered by thin layer of skin; posterior tip extending into parieto-supraoccipital. Nasal slender, slightly curved laterally, mesial border contacting frontal. Fron- tal roughly rectangular; anterior expansion in contact with nasal bone, posterior portion contacting sphenotic and parieto-supraoccipital. Sphenotic trapezoid in shape, contacting parieto-supraoccipital dorsally, compound pterotic posteriorly, second infraorbital ventrally. Compound pterotic roughly pipe-shaped, with slender posterior expansion contacting first dorsal body plate and first lateral-line ossicle. Contact region between compound pterotic and first dorsal body plate covered by area of thick skin. Ventral margin of compound pterotic contacting opercle and cleithrum. Parietosupraoccipital quadrangular with posterior process notched at its tip, sutured with nuchal plate.

Two infraorbital bones, externally visible, covered by thin layer of skin. First infraorbital with slender anterior expansion. Opercle exposed, compact in shape, with free border angular. Preopercle externally visible, slender and covered by thin layer of skin.

Trunk lateral-line with two laterosensory canals, reduced to small ossicles. Two specimens (MUSM 26961, 22.3-24.6 $\mathrm{mm} \mathrm{SL}$ ) with one perforated dorsolateral body plate. Lateralline canal entering neurocranium through compound pterotic, splitting into two branches, pterotic and preoperculomandibular, each with single pore, before entering sphenotic. Sensory canal continuing through compound pterotic, entering sphenotic as temporal canal, which splits into two branches: infraorbital canal, and supraorbital canal entering through frontal bone. Supraorbital canal with two branches: epiphyseal, opening in frontal bone, and anterior, running through nasal bone. Nasal canal with single opening at each end. Infraorbital canal running through entire second infraorbital, extending to infraorbital 1 and opening into two pores. Preoperculomandibular branch giving rise to preoperculomandibular canal, which runs through entire preopercle with three openings, leading to pores 3,4 , and 5, respectively.

Body plates with minute odontodes restricted to posterior margins. Nuchal plate exposed. Cleithrum and mesial process of scapulocoracoid exposed. Minute odontodes scattered over area between scapulocoracoids. Body plates not touching counterparts in specimens up to $24.0 \mathrm{~mm} \mathrm{SL}$, leaving narrow naked groove on medial dorsal and ventral surfaces; gap more conspicuous between dorsal body plates. Dorsolateral body plates $24 *(\mathrm{n}=27)$, one specimen (MUSM $27155,26.9 \mathrm{~mm} \mathrm{SL}$ ) with 23 plates; ventrolateral body plates $21 *$ (25), or 22 (3); dorsolateral body plates along dorsal-fin base $6(3), 7^{*}(10)$, or 8 (15); dorsolateral body plates from adipose fin to caudal-fin base $8 *(27)$, one specimen (MUSM $27155,26.9 \mathrm{~mm} \mathrm{SL}$ ) with seven plates; preadipose platelets $3 *$ (17), or 4 (11). Precaudal vertebrae 8, caudal vertebrae 14, in all cleared-and-stained specimens; five pairs of ribs, first pair conspicuously larger than others.

Dorsal fin roughly triangular; its origin just posterior to second or third dorsolateral body plate. Dorsal spine shorter 


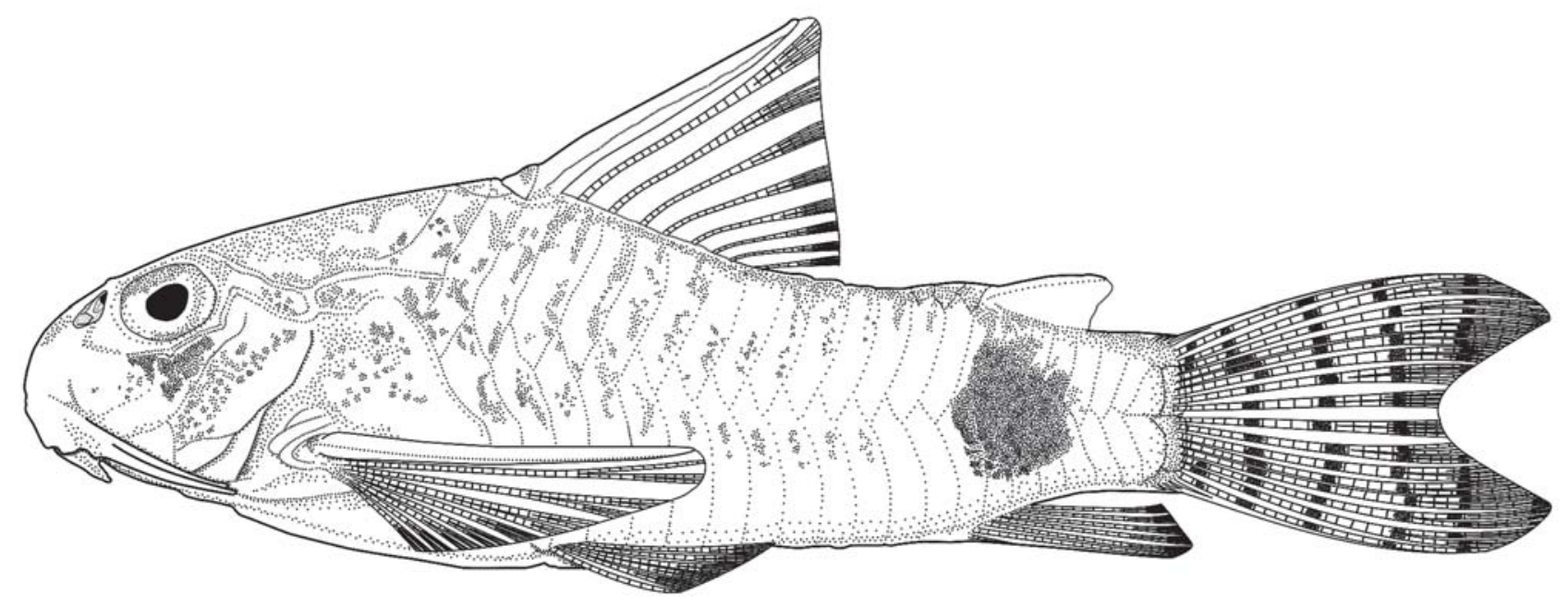

Fig. 2. Corydoras ortegai, MUSM 28000, holotype, $32.7 \mathrm{~mm}$ SL: Peru, Depto. Loreto, Quebrada Coronel Díaz, tributary of río Yaguas. Caudal fin reconstructed after MUSM 27154, $27.7 \mathrm{~mm}$ SL.
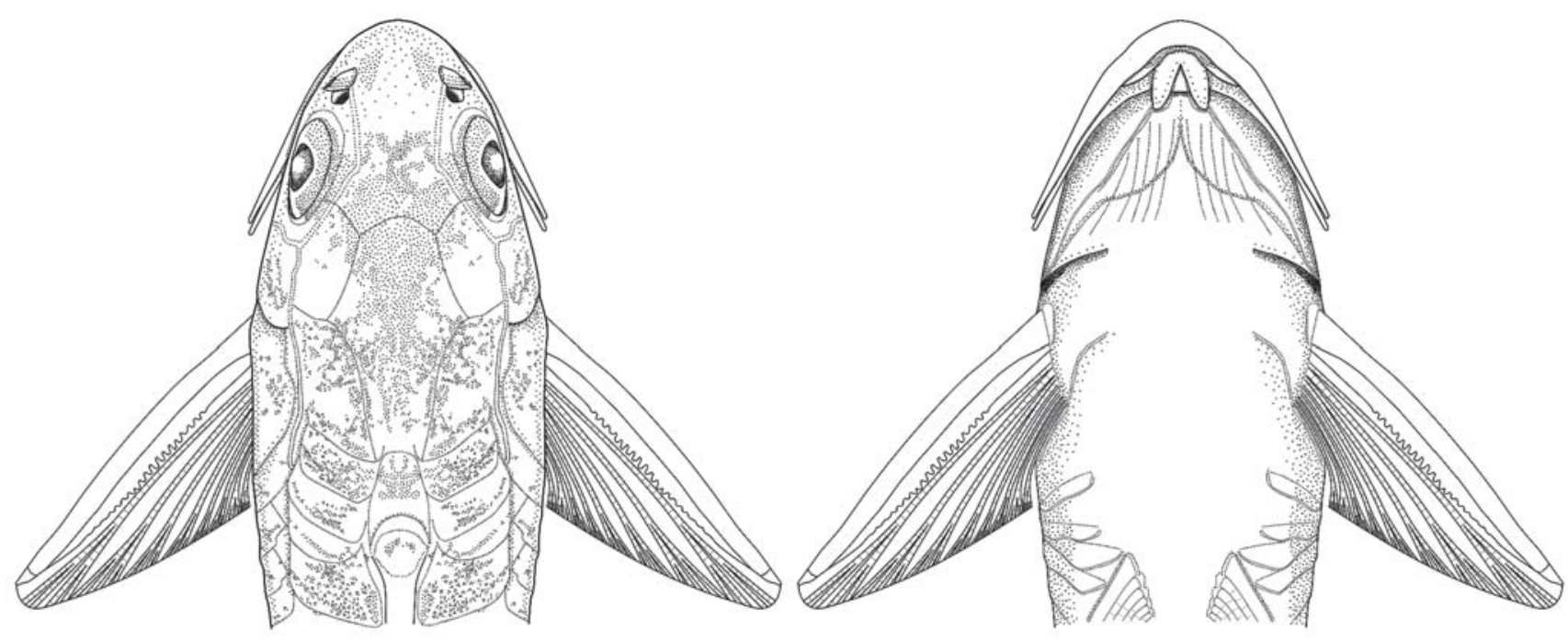

Fig. 3. Dorsal (left) and ventral (right) views of head and pectoral fins of Corydoras ortegai, MUSM 28000, holotype, $32.7 \mathrm{~mm}$ SL: Peru, Depto. Loreto, Quebrada Coronel Díaz, tributary of río Yaguas.

than first branched ray. Anterior margin of dorsal spine smooth; posterior margin with minute serrations. Dorsal-fin rays II, $8^{*}$ (27); II,9 in one specimen (MUSM 26961, $27.0 \mathrm{~mm} \mathrm{SL}$ ). Adipose fin roughly triangular; its origin separated from base of last dorsal-fin ray by 6-8 dorsolateral body plates. Anal fin roughly triangular; its origin located posterior to 12 th or 14th ventrolateral body plates, at vertical through posterior margin of last preadipose platelet. Anal-fin rays ii,5 in all specimens. Pectoral fin triangular; its origin located just posterior to gill opening. Ossified portion of pectoral spine shorter than first branched ray. Distal tip of spine with minute segmented unossified portion. Pectoral spine flattened with smooth anterior margin and small serrations along entire posterior margin, less conspicuous distally; serrations more developed than in dorsal fin spine. Pectoral-fin rays I, $8^{*}(23)$, or I,7 (5). Pelvic fin ellipsoid; its origin just below first ventrolateral body plate, at vertical through intermembrane between second and third branched dorsal-fin rays. Pelvic-fin rays i,5 
in all specimens. Caudal fin bilobed, weakly forked; lower lobe slightly longer. Principal caudal-fin rays i,6/6,i; upper and lower procurrent caudal-fin rays 4 and 5 , respectively. Total number of caudal-fin rays 23. All fins with minute odontodes scattered over all rays.

Color in alcohol. Ground color of head yellowish light brown. Wide, slightly oblique dark brown vertical blotch ("mask") from top of head across anterior and posterior margins of eye to ventral anterior corner of opercle. Scattered chromatophores over snout and outer mental barbel; remaining barbels yellowish light brown. Scattered chromatophores on posterior process of parieto-supraoccipital; more concentrated on its midline. Surfaces of opercle and preopercle with several, relatively large, scattered chromatophores; chromatophores more concentrated on contact region between both bones.

Ground color of trunk uniform light brown. Large, yellowish white area on midregion of cleithrum, surrounded by several scattered chromatophores concentrated posteriorly. All body plates anterior to adipose and anal fins with irregular, short, narrow patches of scattered chromatophores; patches more concentrated just above and below junction of dorsaland ventral-body plates, forming two faint, broken longitudinal stripes that fade posteriorly (Figs. 1, 2). Large, roughly rounded, dark brown blotch midlaterally below adipose fin; blotch fading dorsally and ventrally towards adipose- and anal-fin bases, respectively (Figs. 1,2). Region of body plates junction between both blotches without chromatophores. Body plates at caudal peduncle with few chromatophores, some concentrated on dorsolateral plate just posterior to adipose fin. Several chromatophores scattered over preadipose platelets, extending to adipose spine.

Dorsal and pectoral fins hyaline, with few chromatophores concentrated on spines. Adipose-fin membrane hyaline, with few scattered chromatophores. Anal fin hyaline, with few chromatophores concentrated on first ray. Pelvic fin hyaline. Caudal fin with small, dark brown blotches restricted to rays and arranged into three or four, roughly vertical, narrow bands.

Sexual dimorphism. No sexually dimorphic characters found. Corydoradine catfishes often have dimorphic genital papillae (see, e.g. Britto, 2003), but specimens of C. ortegai display no modifications.

Distribution. Corydoras ortegai is only known from tributaries of the Río Yaguas, a tributary of the lower Río Putumayo, in Departamento Loreto, Peru, very close to the border with Colombia and Brazil (Fig. 4).

Habitat and ecological notes. Corydoras ortegai was mostly found inhabiting lotic habitats in the Río Yaguas basin, a whitewater tributary of Río Putumayo. The Río Yaguas has a muddy-brown color, with soft bottom of clay and sand where

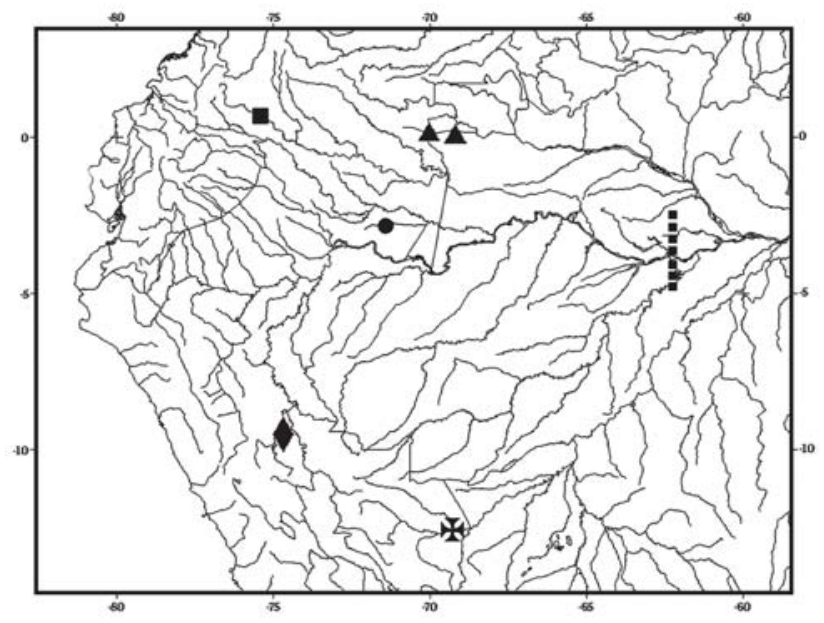

Fig. 4. Northern South America, showing the distribution of Corydoras ortegai (dot), C. panda (diamond), C. reynoldsi (square), C. tukano (triangles), and C. weitzmani (cross). Distribution of $C$. weitzmani is depicted with its center at Puerto Maldonado, capital of the Departamento Madre de Dios in Peru, since precise localities for the species are not known (see text). Segmented line: Purus structural arch.

C. ortegai was relatively abundant. No individuals were captured in the small black or clearwater forest streams, nor lagoons that were also present in the area. The only congener found living syntopically with $C$. ortegai at the type locality was $C$. pastazensis. The region where $C$. ortegai was discovered has a high diversity of fishes (207 species recorded), and it is being proposed as a new protected area in Peru (Hidalgo \& Olivera, 2004).

Etymology. After Hernán Ortega Torres, curator of the fish collection of the Museo de Historia Natural, Universidad Nacional Mayor de San Marcos, in recognition of his deep interest in the freshwater fish fauna of Peru and his contributions to our knowledge of its diversity.

\section{Discussion}

Interrelationships within Corydoras are poorly known. Britto (2003) published the most comprehensive phylogenetic study of Corydoradinae catfishes to date. In this work the monophyly and limits of Corydoras were hypothesized, and monophyletic units within it established; however, interrelationships remained poorly resolved among most of the 82 species examined. Inclusion of Corydoras ortegai and $C$. tukano in the data matrix compiled by Britto (2003) recovered both as sister species. This relationship is based on two character-states: presence of small inner expansion on second infraorbital, leaving a naked area in the posterior wall of ocular cavity (Britto, 2003: character 17), and dorsal lamina on anguloarticular triangular in shape (Britto, 2003: character 37). 
In addition, both species, were placed in a small assemblage that has Corydoras panda as its most basal taxon. This assemblage is supported by absence of odontodes on infraorbitals and opercle (Britto, 2003: characters 13 and 44). The monophyly of this assemblage, however, is not well supported, because it is defined by highly homoplastic characters, with optimizations depending on tree topology.

Color pattern provides additional evidence for a close phylogenetic relationship between Corydoras ortegai and C. tukano. In the original description of Corydoras tukano, Britto \& Lima (2003) indicated the presence of a unique color pattern shared between this species, Corydoras reynoldsi, and C. weitzmani. That pattern is composed of light ground coloration on body, presence of a dark bar ("mask") across the orbit, and two large, dark blotches midlaterally on trunk, one at the level of dorsal fin, and a second at the level of adipose fin. Britto \& Lima (2003) used this color pattern to propose a close relationship among these three species. Considering that Corydoras ortegai lacks the anterior trunk blotch and is, according to the information available, the sister species of C. tukano, its discovery poses doubts about the recognition and interpretation of this color pattern when it is treated as a whole. Furthermore, Corydoras panda, which possesses a color pattern similar to Corydoras ortegai, and is closely related to this species and C. tukano at a more inclusive level, reinforces the question as to how this color pattern should be evaluated. Treating the components of the color pattern (dark "mask" and trunk blotches) as independent characters (states absent/present), and including them in Britto's (2003) data matrix sheds some light on this question. Accordingly, the presence of a dark mask across the orbit is interpreted as a highly homoplastic character, occurring in several lineages of Corydoras (for a partial list of Corydoras species possessing a mask, see Britto \& Lima, 2003: 89). The same is true for the presence of a caudal-peduncle blotch (which was already present in Britto, 2003: character 78). The trunk blotch at the dorsal-fin level is present in Corydoras tukano and it is homoplastic with several Corydoras species, such as C. ellisae Gosline and C. paleatus Jenyns. The paucity of preserved material of Corydoras reynoldsi and $C$. weitzmani did not allow their inclusion in the analysis. Inclusion of both species, as well as other Corydoras species that show "masks" and/or "body blotches", are necessary for a clear understanding about the evolution of that color pattern, and whether, in some cases, "masks" and trunk blotches evolve together or not.

Although still uncertain at this time, the purported monophyly of an assemblage containing Corydoras ortegai, $C$. tukano, C. reynoldsi, C. weitzmani, and C. panda is suggestive of a pattern of western Amazon endemicity. A "Western Amazonian" area of endemism for fishes has been suggested by other authors (e.g. Kullander, 1986; Reis, 1998b; Wilkinson et al., 2006; Hubert \& Renno, 2006) and is here equated to the sedimentary basins situated west of the Purus Arch (see Räsänen et al., 1992: fig. 1), the eastern divide of the Amazon basin prior to the late Miocene (see Lundberg et al., 1998, and references therein). Four of the five Corydoras belonging to this putatively monophyletic group occur in this region: Corydoras reynoldsi is only known from its type locality in the upper río Caquetá basin, Colombia (Myers \& Weitzman, 1960), C. panda in the upper río Ucayali basin, Peru (Nijssen \& Isbrücker, 1971), C. ortegai in the lower río Putumayo basin, Peru, and C. weitzmani in the rio Madre de Dios Basin, Peru (type locality mistakenly reported as Cuzco on the upper rio Villcabamba/Ucayali at the Andean cordillera; see Fuller \& Evers, 2005: 266). The onl exception is $C$. tukano, in the rio Tiquié, a tributary of the rio Uaupés in the upper rio Negro basin (Britto \& Lima, 2003). The rio Uaupés drains the westernmost portion of the Guianan Shield (Brasil, 1976), an area distinct in its geological evolution (see, e.g. Lundberg et al., 1998) (see Fig. 4 for a distribution map encompassing all referred species). The rio Tiquié is one of the westernmost tributaries of the rio Negro basin, and shares an extensive divide with the Río Caquetá/Japurá basin (more specifically, the Río Pira-Paraná, tributary of Río Apapóris) that drains into the upper Amazon. The occurrence of two additional species, Creagrutus tuyuka (Characidae) and Cetopsis parma (Cetopsidae) in the rio Tiquié further suggest a biogeographical relationship between this river and rivers draining the Western Amazon. The sister taxa of Creagrutus tuyuka (Characidae), are C. kunturus and C. amoenus, both of which occur in the upper Amazon basin in Peru, Ecuador, and Colombia (Vari \& Harold, 2001; Vari \& Lima, 2003), whereas Cetopsis parma (Cetopsidae) is only known from the upper Amazon basin and rio Tiquié (Vari et al., 2005).

Comparative material. A list of the comparative material is available in Britto \& Castro (2002) and Britto (2003). In addition, the following material was studied: Corydoras panda (all from Peru, Estado Huanuco, Aquas Amarillas, tributary of Río Pachitea, Río Ucayali system) BMNH 1969.7.15.8, holotype; BMNH 1969.7.15.9, 1, paratype. C. reynoldsi CAS-SU 50702, 2, Colombia, Provincia Caquetá, small stream tributary to the Río Orteguaza opposite the town and a air base known as Tres Esquinas, paratypes. C. tukano (all from Brazil, Estado do Amazonas) MNRJ 25355, 2, 24.4-32.0 mm SL, igarapé Cabari, comunidade de Coração de Maria, paratypes; MZUSP 64096, 4, 28.2-38.0 mm SL), rio Tiquié, comunidade de Boca do Sal, paratypes; MZUSP 65689, 2, 33.2-38.5 mm SL, rio Tiquié, one hour by boat below comunidade de Cunuri, below Cachoeira do Tucano, paratypes; MZUSP 81153, 9, 6 cs, 35.4-37.2 mm SL, 6 cs, 20.9-38.3 mm SL, rio Tiquié, between the comunidades de Caruru and Boca de Sal, paratypes; MZUSP 81179, 2, 34.0$36.1 \mathrm{~mm}$ SL, rio Tiquié, comunidade de Boca do Sal, paratypes; MZUSP 81194, 5, 34.5-40.3 mm SL, rio Tiquié, comunidade de Caruru, beaches in pool below the fall, paratypes; MZUSP 81216, 2, 17.1-21.3 mm SL, rio Tiquié, between the comunidades de São Domingos Sávio and Jabuti, paratypes; MZUSP 81244, 16, 20.3-41.4 mm SL, igarapé Cabari, comunidade de Coração de 
Maria, paratypes; MZUSP 82100, $40.9 \mathrm{~mm}$ SL, rio Tiquié, comunidade de Caruru, beaches in pool below the fall, holotype.

\section{Acknowledgements}

We thank the Field Museum of Natural History, Chicago for financially supporting the expedition (Rapid Biological Inventory of Ampiyacu, Apayacu, Yaguas and Medio Putumayo region) where all specimens were collected. We wish to thank William Crampton for the invitation to the second author to join one of the expeditions of the "Proyecto Ucamara" (NSF DEB 0102593), in the aftermath of which material of the new species was identified as new at the MUSM fish collection. Hernan Ortega assisted the second author during his stay at Lima. Eduardo Baena prepared Figs. 1, 4, and 5, and also assisted with the pictures. James Maclaine $(\mathrm{BMNH})$ kindly provided photographs from the holotype and paratypes of Corydoras panda deposited at that institution. MRB received financial support from CNPq (grants 300189/ 03-6, 502975/2005-9, and 474788/2006-7). The authors are participants of the All Catfish Species Inventory (NSF 0315963).

\section{Literature Cited}

Aquino, A. E. \& S. A. Schaefer. 2002. The temporal region of the cranium of loricarioid catfishes (Teleostei: Siluriformes): Morphological diversity and phylogenetic significance. Zoologischer Anzeiger, 241: 223-244.

Arratia, G. \& M. Gayet. 1995. Sensory canals and related bones of tertiary siluriform crania from Bolivia and North America and comparison with recent forms. Journal of Vertebrate Paleontology, 15: 482-505.

Brasil. Departamento Nacional de Produção Mineral. 1976. Projeto Radambrasil. Levantamento dos recursos naturais. Vol. 11. Folha NA. 19. Pico da Neblina. Geologia, geomorfologia, pedologia, vegetação e uso potencial da terra. Rio de Janeiro, 380p + maps.

Britto, M. R. 2003. Phylogeny of the subfamily Corydoradinae Hoedeman, 1952 (Siluriformes: Callichthyidae), with a definition of its genera. Proceedings of the Academy of Natural Sciences of Philadelphia, 153: 119-154.

Britto, M. R. \& R. M. C. Castro. 2002. A new corydoradine catfish (Siluriformes: Callichthyidae) from the upper Paraná and São Francisco: the sister-group of Brochis and most of Corydoras species. Copeia, 2002: 1006-1015.

Britto, M. R. \& F. C. T. Lima. 2003. Corydoras tukano, a new species of corydoradine catfish from the rio Tiquié, upper rio Negro basin, Brazil (Ostariophysi: Siluriformes: Callichthyidae). Neotropical Ichthyology, 1: 83-92.

Burguess, W. E. 1993. Three new species of catfishes of the genus Corydoras (Callichthyidae: Siluriformes). Tropical Fish Hobbyist, 41: 152-158.

Burguess, W. E. 1997. Corydoras coriatae, a new species of callichthyid catfish related to Corydoras fowleri. Tropical Fish Hobbyist, 45: 138, 140, 141-142, 144, 146, 147-148.

Fuller, I. A. M. \& H. G. Evers. 2005. Identifying Corydoradinae catfish. Aspidoras-Brochis-Corydoras-Scleromystax \& Cnumbers. Ian Fuller Enterprises/A.C.S. GmbH (Aqualog), Worcestershire/Rodgau, 384p.
Hidalgo, M. \& R. Olivera. 2004. Peces. Pp: 62-67. In: Pitman, N., R. C. Smith, C. Vriesendorp, D. Moskovits, R. Piana, G. Knell, \& T. Watcher (Eds.). Perú: Ampiyacu, Apayacu, Yaguas, Medio Putumayo. Rapid Biological Inventories Report 12. Chicago, Illinois: The Field Museum.

Hubert, N. \& J. F. Renno. 2006. Historical biogeography of South American freshwater fishes. Journal of Biogeography, 33: 14141436.

Kullander, S. O. 1986. Cichlid fishes of the Amazon River drainage of Peru. Department of Vertebrate Zoology, Swedish Museum of Natural History, Stockholm, 431p.

Lundberg, J. G. 1970. The evolutionary history of North American catfishes, Family Ictaluridae. Unpublished Ph.D. Dissertation, The University of Michigan, Ann Arbor. xiii $+524 p$.

Lundberg, J. G., L. G. Marshall, J. Guerrero, B. Horton, M. C. S. L. Malabarba \& F. Wesselingh. 1998. The stage for Neotropical fish diversification: a history of Tropical South American rivers. Pp. 13-48. In: Malabarba, L.R., R. E. Reis, R. P. Vari, Z. M. Lucena \& C. A. S. Lucena (Eds.), Phylogeny and classification of Neotropical Fishes. Porto Alegre, EDIPUCRS, 603p.

Myers, G. S. \& S. H. Weitzman. 1960. Two new fishes collected by General Thomas D. White in eastern Colombia. Stanford Ichthyological Bulletin, 7: 98-109.

Nijssen, H. \& I. J. H. Isbrücker. 1971. Two new species of the catfish genus Corydoras from Brazil and Peru (Pisces, Siluriformes, Callichthyidae). Beaufortia, 18: 183-189.

Nijssen, H. \& I. J. H. Isbrücker. 1986. Review of the genus Corydoras from Peru and Ecuador (Pisces, Siluriformes, Callichthyidae). Studies on Neotropical Fauna and Environment, 21: 1-68.

Räsänen, M., R. Neller, J. Sallo \& H. Jungner. 1992. Recent and ancient fluvial deposition systems in the Amazonian foreland basin, Peru. Geological Magazine, 129: 293-306.

Reis, R. E. 1997. Revision of the neotropical catfish genus Hoplosternum (Ostariophysi, Siluriformes, Callichthyidae), with the description of two new genera. Ichthyological Exploration of Freshwaters, 7: 299-326.

Reis, R. E. 1998a. Anatomy and phylogenetic analysis of the neotropical callichthyid catfishes (Ostariophysi, Siluriformes). Zoological Journal of the Linnaean Society, 124: 105-168.

Reis, R. E. 1998b. Systematics, biogeography, and the fossil record of the Callichthyidae: a review of the available data. Pp. 351362. In: Malabarba, L. R., R. E. Reis, R. P. Vari, Z. M. Lucena \& C. A. S. Lucena (Eds.), Phylogeny and classification of Neotropical Fishes. Porto Alegre, EDIPUCRS, 603p.

Reis, R. E. 2003. Family Callichthyidae (armored catfishes). Pp. 291-309. In: Reis, R. E., S. O. Kullander \& C. J. Ferraris (Eds.). Check List of the Freshwater Fishes of South and Central America. Porto Alegre, EDIPUCRS, 729p.

Reis, R. E., S. O. Kullander \& C. J. Ferraris (Eds.). 2003. Check List of the Freshwater Fishes of South and Central America. Porto Alegre, EDIPUCRS, 729p.

Schaefer, S. A. 1988. Homology and evolution of the opercular series in the loricarioid catfishes (Pisces: Siluroidei). Journal of Zoology, 214: 81-93.

Schaefer, S. A. \& A. Aquino. 2000. Postotic laterosensory canal and pterotic branch homology in catfishes. Journal of Morphology, 246: 212-227.

Taylor, W. R. \& G. C. Van Dyke. 1985. Revised procedures for staining and clearing small fishes and other vertebrates for bone and cartilage study. Cybium, 9: 107-119. 
Vari, R. P., C. J. Ferraris Jr. \& M. C. C. de Pinna. 2005. The Neotropical whale catfishes (Siluriformes: Cetopsidae: Cetopsinae), a revisionary study. Neotropical Ichthyology, 3: 127-238.

Vari, R. P. \& A. S. Harold. 2001. Phylogenetic study of the Neotropical fish genera Creagrutus Günther and Piabina Reinhardt (Teleostei: Ostariophysi: Characiformes), with a revision of the cis-andean species. Smithisonian Contributions to Zoology, 613: 1-239.

Vari, R. P. \& F. C. T. Lima. 2003. New Creagrutus (Ostariophysi: Characiformes: Characidae) from the rio Uaupés basin, upper rio Negro, Brazil. Copeia 2003: 583-587.

Wilkinson, M. J., L. G. Marshall \& J. G. Lundberg. 2006. River behavior on megafans and potential influences on diversification and distribution of aquatic organisms. Journal of South American Earth Sciences, 21: 151-172.

Submitted December 2006

Accepted March 2007 